\title{
Communication Patterns of Management in Improving Staff Productivity
}

\author{
M. Nasor \\ \{nasor@radenintan.ac.id\} \\ Faculty of Dakwah and Communication Science, Universitas Islam Negeri Raden Intan Lampung, Jl. \\ Letkol H. Endro Suratmin Sukarame, Bandar Lampung, Indonesia

\begin{abstract}
The pattern of communication in an organization may affect staff work productivity. Thus, it is necessary for an organization to find out whether or not its communication pattern support work productivity. This research was aimed at revealing the communication patterns of the management of STAI An-Nur Jati Agung South Lampung to their staffs and the effect towards the work productivity. A descriptive qualitative research with evaluative approach was conducted to meet the objective of this research. It was, then, found out that the patterns of communication conducted by the management of STAI An-Nur South Lampung to the staffs include individual, group, and mass communication which positively contribute to the improvement of professionalism, motivation, creativity, and innovation. Eventually, these all affect work productivity.
\end{abstract}

Keywords: Communication Pattern, Management, and Productivity.

\section{Introduction}

The patterns of communication in an organization are closely related to the work productivity of the staffs due to the enhancement of their motivation. Motivation that can provide satisfaction to individuals in the work will affect their productivity (Zainun, 2006). Surely, motivation from the manager can encourage staffs to achieve work productivity. The manager should be able to motivate his staffs to achieve a certain level of productivity. Staffs directed to a positive attitude will show high motivation and work; otherwise they will show low motivation and work (Mangkunegara, 2005) .

Based on the pre-survey conducted at Islamic Studies Higher Education (STAI) An-Nur Jati Agung, South Lampung, it was apparent that the management showed good performance, in terms of communication with the staffs. They could establish good communication with the staffs, so that they can change their behavior (An observation on January 2, 2014). Good communication is the accomplishment of information, ideas, ideas or skills, through symbols or symbols to others to change attitudes and behavior (Bernard and Steiner, 1964). Through his extensive knowledge a manager can always provide guidance to his staffs that have difficulty and lack of discipline in performing their duties.

Further, STAI An-Nur Jati Agung South Lampung has experienced some progress and change of leadership. It is carried out to ascertain its role as a higher education institution engaged in education and Islamic dakwah by managing several courses (Andi Warisno, Head of STAI An-Nur Jati Agung South Lampung, and an Interview on February 3, 2014).

In the process of achieving educational objectives, STAI An-Nur Jati Agung, South Lampung is supported by lecturers and administration staffs. Based on the survey, a lot of staff members were less skilled in operating tools or media-based technology, such as computers, laptops, internet, and others. The implication of administrative process is less current, less accurate in accessing information, and not maximum in serving the lecturers, student, and 
society (An observation on January 4, 2014). In accordance with the above situation, the problem was formulated as follows: "How is the pattern of management communication in improving staff work productivity at STAI An-Nur Jati Agung South Lampung?"

\section{Research Method}

This research used evaluative approach by applying context, input, process, output, and outcomes. It is meant to see the effectiveness of a program, by measuring matters related to program implementation (Arikunto, 2007). While the context of this research is the problems associated with the specific educational environment in the form of support requests that affect the input, process, output, and outcome.

In this study, the data were extracted through two sources, namely primary data source and secondary data source. Primary data source is the management and staffs of STAI An-Nur Jati Agung South Lampung, by purposive and snowball sampling. Purposive sampling is a technique of taking data sources with certain considerations, as well as sampling techniques in snowball sampling. Sources of secondary data are obtained from associations of student guardians, students, documents, records, applicable regulations, books or supporting literature.

\section{Results And Discussion}

\subsection{Communication Pattern between Management and Staffs at STAI An-Nur South Lampung}

It is previously mentioned that communication is an activity undertaken by communicators to convey messages, ideas, thoughts, or ideas to communicant in order to change attitudes and behavior. Communication that occurs in STAI An-Nur South Lampung is in the form of various communication patterns of individual communication, group communication, and mass communication.

\subsubsection{Individual Communication Patterns}

Interpersonal communication plays a role in transferring messages/information from someone to others (individual) in the form of ideas, messages, thoughts, feelings, events, and more. This interpersonal communication is a bridge for every individual physically interconnected, sharing knowledge, sharing feelings, and making it possible to know more about one's circumstances.

STAI An-Nur South Lampung has been conducting interpersonal communication, as management often approach or summon staffs to interview or exchange ideas about the success or constraints faced. Individual communication pattern promotes such important elements as honesty and fairness. It may also create openness in issuing ideas so that it will be more effective in achieving results. This type of communication also brings about the existence of empathy factor in communication.

Obviously, empathy is a psychological factor that relates to one's feelings. This kind of psychological condition may enhance the productivity, too. This is practiced by the management of STAI An-Nur South Lampung to the staffs through attention, understanding, and caring to help others (Andi Warisno, Head of STAI An-Nur Jati Agung South Lampung, an Interview on October 5, 2014).

The pattern of communication above has its own effectiveness to change attitudes/opinions, feelings, and behavior of a person. It may cause such positive impacts as 
openness and willingness to respond to problems, empathy, effective communication support, positive thinking, and equality in which both parties respect each other (Wiryanto, 2004). Another advantage is that it allows proximity relationship between managers and staffs (Wright, 1986).

\subsubsection{Group Communication Patterns}

The management of STAI An-Nur South Lampung has divided or grouped the staffs into certain parts or units which regularly interact to form a conducive network. The division of the group is intended to let them focus their duties and functions accordingly (Andi Warisno, Head of STAI An-Nur Jati Agung South Lampung, an Interview on October 1, 2014). The communication process conducted by the people in the group will bring influence to other groups, in terms of finding the proper solution of problems faced by the organization (Abdul Adib, Secretary of Education Department of STAI An-Nur Jati Agung South Lampung, an Interview on October 10, 2014).

There are several functions of group communication, namely: social relationships, the existence of education in groups, the function of persuasion in others, the problem-solving function, and the therapeutic functions (Bungin, 2006).

\subsubsection{Mass Communication Patterns}

Indeed the mass media has a function and a series of usability and can play a huge role. STAI An-Nur South Lampung to support the success of his program has been utilizing the mass media in the communication process. Many types and forms of media as a means of communication such as: leaflets, banners, billboards, bulletin boards, books, television, radio, newspapers, journals, and other forms of public nature (Agus Sujarwo, Vice Head of STAI An-Nur Jati Agung South Lampung, an Interview on October 10, 2014).

This pattern of communication has long been run and seems to have its own effectiveness in disseminating information about the progress of STAI An-Nur South Lampung. The success and progress of STAI An-Nur South Lampung has been supported by the mass media as a communication tool (Abdul Adib, Secretary of Education Department of STAI An-Nur Jati Agung South Lampung, an Interview on October 10, 2014). The awareness of the management of STAI An-Nur South Lampung to utilize mass media is considerably high.

Further, the effect of mass media communication can be a state of changing knowledge, changing attitudes, or moving our behavior (Rakhmat, 1994). In addition, there are three kinds of mass media effects as revealed above (changing knowledge, changing attitudes, or moving our behavior) in the field of science known as cognitive effects, affective effects, and motoric effects (Jahi, 1988).

\subsection{The Enhancement of Staff Productivity}

\subsubsection{Work performance}

Job performance is needed in an organization that employs some people as the staffs. It is intended to see the performance of staffs based on their success in achieving the goals that have been determined by the management. In general, STAI An-Nur South Lampung is successful in the implementation of education through increased productivity done by the staffs by giving them motivation/passion to work. 
In addition, leadership is a process to influence others in inspiring and motivating their activities in order to achieve organizational goals (Jones and George, 2003). This can be seen from its performance, such as: discipline, suitability of field done, result achieved, cooperation, finished on time, and creativity of staffs. The counseling of management to staffs is one of the management efforts to develop and improve staff productivity (Agus Sujarwo, Vice Head of STAI An-Nur Jati Agung South Lampung, an Interview on October 10, 2014).

\subsubsection{Level of Staff Responsibility}

In STAI An-Nur South Lampung, manager is required to improve the quality of staffs in the field of work. The assessment of the responsibilities of staffs is seen from the ability to complete tasks, discipline, the use of infrastructure, and the quality of the end result of a job. The staffs have worked optimally so that they can complete their main tasks well. In addition, the staffs are also in work based on understanding and abide by the rules applied in STAI AnNur South Lampung. They work on time because they are afraid to be labeled as unprofessional staffs (Andi Warisno, Head of STAI An-Nur Jati Agung South Lampung, an Interview on October 10, 2014).

The existence of the responsibilities of the staffs above is the result of direction and the results of the good management to keep improving the quality of productivity in accordance with the vision and mission of the institution. It is in line with the definition of leadership stating that it is such effort to lead people towards the vision and the mission and provides inspiration for the desired goal to be achieved (Slatter, Lovett and Barlow, 2006).

\subsubsection{Staff Creativity}

A staff having creativity will certainly work skillfully and implement proper strategies to achieve success. The creativity is indicating a staff that has knowledge and competence. A creative and skillful staff can act as a good working partner in achieving productivity (An observation on October 10, 2014). Institutions that have creative staff will serve as a benchmark for the nature of competence and credibility.

Leadership is a process that inspires someone/others to work hard in an effort to complete important tasks (Schermerhon and Chappell, 2000). Such properties can revive and increase the positive value of agencies/institutions in the community. Another value is the nature of open, honest staffs, the ability to be a good team worker, able to respect other staffs, and diligent in completing the task.

\subsubsection{Level of Staff Discipline}

An organization needs its staffs to be disciplined in performing their duties. Discipline is an action complying with norms, rules, or custom of prevailing and commonly agreed. In addition, also discipline in doing a job in accordance with instructions, such as coming on time, home in accordance with the time specified, the completion of work on time, and bring good results and satisfactory (An observation on October 5, 2014). The discipline level of the staff of STAI An-Nur South Lampung is considerably good.

Description above provides an understanding that the management of STAI An-Nur South Lampung has done much to provide guidance and direction to staffs for work discipline. The management realizes discipline is very important in an institution. The better the discipline of staffs in an organization is, the higher the achievement and work productivity can be achieved. Conversely, without staff discipline, it is difficult for the organization to achieve optimal results. Discipline is a reflection of a high sense of responsibility for the task it carries. 


\subsubsection{Level of Staff Cooperation}

The ability of staffs in cooperation is very important in solving the problem. This cooperation is based on willingness to participate and help other staffs. This is an effort to achieve usefulness and results so that all staffs will work collaboratively to achieve as optimum results as possible. The ability of staffs to cooperate will also be able to ease the burden of the task and find a solution or way out of the problems that are faced.

In carrying out every activity or everyday activities, cooperation is very important to complete the work in a timely and quality. Any form of activities, if executed in a timely and proper manner, will be accomplished according to the time specified.

\section{Conclusion}

Patterns of communication conducted by the Leaders STAI An-Nur South Lampung to staffs include individual, group, and mass communication. This interpersonal communication is an individual meeting physically, sharing knowledge, sharing feelings, and being able to know deeper into a person's circumstances. Group communication is the existence of a group of humans forming a network consisting of a group of people. The pattern of mass communication is considered very amazing because of the greater reach of a large number of people.

When the above communication pattern is done repeatedly, it will all improve professionalism, motivation, creativity and innovation which eventually may affect productivity. Increased staff productivity includes staff performance, staff responsibility, staff creativity, staff discipline, and staff cooperation levels.

\section{Acknowledgements}

The author firstly would like to thank Dr. Andi Warisno, M. Pd. I, the Head of STAI AnNur Jati Agung South Lampung and all of the staffs who have been very helpful in providing the data needed for this study. Besides, high appreciation also goes to Bambang Irfani, M. Pd for the valuable insights and technical assistance to make this article well-composed.

\section{References}

[1] Arikunto, S. (2007) Penelitian Program Pendidikan. Jakarta: Rajawali Press.

[2] Bernard, B. and Steiner, G. A. (1964) Human Behavior: An Inventory of Scientific Finding. New York: Harcourt Brace Javanovich.

[3] Bungin, B. (2006) Sosiologi Komunikasi. Jakarta: Kencana Prenada Media Group.

[4] Jahi, A. (1988) Komunikasi dan Pengembangan Perluasan di Negara-Negara Dunia Ketiga. Jakarta: PT Gramedia.

[5] Jones, G. R. and George, J. M. (2003) Contemporary Management. New York: McGraw Hill Inc.

[6] Mangkunegara, A. P. (2005) Evaluasi Kinerja Sumber Daya Manusia. Bandung: PT Rafika Aditama.

[7] Rakhmat, J. (1994) Psikologi Komunikasi. Bandung: Rosyda Karya.

[8] Schermerhon, J. R. \& and Chappell, D. S. (2000) Introducing Management. New York: Wiley.

[9] Slatter, S., Lovett, D. and Barlow, L. (2006) Leading Corporate Turnaround. London: John Welly \& Sons Ltd. 
[10] Wiryanto (2004) Pengantar Ilmu Komunikasi. Jakarta: PT Gramedia Grafindo.

[11] Wright, C. R. (1986) Sosiologi Komunikasi Massa. Edited by J. Rakhmat. Bandung: Rosyda Karya.

[12] Zainun, B. (2006) Manajemen dan Motivasi. Jakarta: Balai Aksara. 